\title{
Assessment of therapeutic education conducted by nurses in patients with type 2 diabetes in the context of the sense of coherence
}

\author{
Ocena edukacji terapeutycznej prowadzonej przez pielęgniarki u pacjentów z cukrzycą typu 2 \\ w kontekście poczucia koherencji
}

Beata Ogórek-Tęcza', Sylwia Sudoł²

\begin{abstract}
'The Department of Theory and Basics of Nursing, the Institute of Nursing and Midwifery
The Faculty of Health Sciences of the Jagiellonian University Medical College, Cracow/ Pracownia Teorii i Podstaw Pielęgniarstwa, Instytut Pielęgniarstwa i Położnictwa, Wydział Nauk o Zdrowiu, Uniwersytet Jagielloński Collegium Medicum, Kraków 2 Intensive Care Unit, The Department of Infectious Diseases, the Jagiellonian University Hospital, Cracow/ Oddział Intensywnej Opieki Medycznej, Klinika Chorób Zakaźnych, Szpital Uniwersytecki, Kraków
\end{abstract}

CORRESPONDING AUTHOR/AUTOR DO KORESPONDENCJI:

Beata 0górek-Tęcza

Pracownia Teorii i Podstaw Pielęgniarstwa

Instytut Pielęgniarstwa i Położnictwa

Wydział Nauk o Zdrowiu, Uniwersytet Jagielloński

Collegium Medicum Kraków

ul. Michałowskiego 12, 31-126 Kraków e-mail: mhtecza@cyf-kr.edu.pl

Cel pracy. 0cena efektywności edukacji terapeutycznej prowadzonej przez pielęgniarki pracujące w oddziałach internistycznych prowadzonej u pacjentów z rozpoznaną cukrzycą typu 2 w kontekście poczucia koherencji.

Materiał i metody. Badaniem ankietowym objęto 100 pielęgniarek pracujących w oddziałach internistycznych. W badaniach efektywności edukacji terapeutycznej posłużono się autorskim kwestionariuszem ankiety, natomiast poczucie koherencji badanych pielęgniarek zmierzono za pomocą kwestionariusza orientacji życiowej SOC-29.

Wyniki. Edukacja terapeutyczna prowadzona przez pielęgniarki, które ukończyły dodatkowe kształcenie podyplomowe była procesem bardziej planowym i obejmowała swoim zakresem większą liczbę tematów. Wysokie poczucie koherencji koreluje z lepszą efektywnością oddziaływań edukacyjnych. Ponad połowa badanych pielęgniarek (56\%) cechowała się średnim, a 44\% wysokim poczucie koherencji, co miało znaczenie dla efektywności prowadzonej edukacji zdrowotnej. Liczba napotykanych czynników utrudniających edukację pacjentów zależy od poziomu poczucia koherencji. Badani z wysokim poczuciem koherencji napotykają więcej trudności, niż osoby ze średnim poczuciem koherencji.

Wnioski. Pielęgniarki deklarujące realizację edukacji terapeutycznej pacjentów wykorzystywały wiedzę zdobytą podczas kształcenia podyplomowego. Badane, które takie kształcenie odbyły poruszały podczas edukacji szerszy wachlarz tematów. Wysokie poczucie koherencji jest istotnym czynnikiem w realizacji funkcji edukacyjnej pielęgniarki, a poprawa efektywności edukacji tego rodzaju może nastąpić dzięki, szerszemu uwzględnianiu tej problematyki w kształceniu uniwersyteckim oraz podyplomowym.

Słowa kluczowe:

ABSTRACT edukacja zdrowotna pacjenta, cukrzyca typu 2, pielęgniarka, poczucie koherencji

\section{ASSESSMENT OF THERAPEUTIC EDUCATION CONDUCTED BY NURSES IN PATIENTS}

\section{WHH TYPE 2 DIABEIES IN THE CONUEXI OF THE SENSE OF COHERENC:}

Aim. Assessment of the effectiveness of therapeutic education conducted by nurses working in the internal medicine wards in patients with diagnosed type 2 diabetes in the context of the sense of coherence.

Material and methods. The survey was carried out among 100 nurses working in the internal medicine wards. In the assessment of the effectiveness of therapeutic education, the authors' survey questionnaire was used, whereas the sense of coherence of the surveyed nurses was measured by means of $\mathrm{SOC}-29$ life orientation questionnaire.

Results. Therapeutic education conducted by nurses who completed postgraduate studies was a more planned process and covered more topics. A high sense of coherence correlates with a wider range of educational interactions. Over half of the surveyed nurses (56\%) showed an average sense of coherence and $44 \%$ - a high sense of coherence, what was significant for the effectiveness of conducted health education. The number of encountered factors hindering the education of patients depends on the level of the sense of coherence. The surveyed with a high sense of coherence face more difficulties than those with an average sense of coherence. 
Conclusions. The nurses declaring the implementation of therapeutic education of patients used the knowledge gained during postgraduate education. Those who completed such studies covered a wider range of topics during the education process. A high sense of coherence is an important factor, significant in the implementation of the educational function of the nurse, and the improvement of the effectiveness of this kind of education can be achieved thanks to wider consideration of these issues at universities and postgraduate education.

Key words: $\quad$ patient's health education, type 2 diabetes, nurse, sense of coherence

\section{INTRODUCTION}

A prerequisite for health education is undertaking cross-sectoral and interdisciplinary activities for the patient involved in the process of education. The complexity of the issues of adult education and the variety of skills of the people who are responsible for carrying it out is becoming a challenge and requires involvement of different human resources. In the health care sector, the statutory responsibility for patient's health education is attributed to both doctor and nurse, or other member of the therapeutic team who looks after the patient and/or their relatives [1]. The implementation of therapeutic education in patients with type 2 diabetes is possible when it is conducted by people representing different professions and comprehensive knowledge not only in medical sciences but also in psychology, pedagogy and teaching methodology [2].

The patient's health education is defined as “... a process involving educational interaction and learning directed at the patient and/or their environment, i.e. consecutive, logically and causatively related actions undertaken to bring about changes in behaviour" [3].

The education of patients, especially chronic patients, is a component of therapeutic procedure and it should accompany the stages of diagnosis, treatment and nursing, thus making it easier for the patients to make fully informed decisions concerning the whole therapeutic and nursing process [1].

The patient's diabetes education contributes to a proper understanding of the nature of the disease by spreading knowledge and improving the patient's awareness. It provides the patient with information on self-control, recommended diet and proper physical activity, as well as the ability to diagnose diabetes complications [4].

It should be made clear to the patient that diabetes education and self-control are equivalent and integral elements of the process of treatment and that this education determines the improvement of the quality of life [5]. Supporting and motivating patients are essential elements of diabetes education $[3,5]$.

Therapeutic education, as a continuous process, should be repeated periodically in order to consolidate the acquired theoretical knowledge and to provide new information, taking into account the patient's education and level of intelligence $[1,2]$.

The process of education requires involvement, effort and self-containment, and the statutory autonomy of the nurse in this area should be supported by personality traits. The conception of the sense of coherence created by Antonovsky, defined as ... "a general life orientation, attitude towards life and the belief that it makes sense and that it is worth taking the challenges it brings" [6], indicates that such belief has a significant impact on attitudes towards many life activities, including work. The components of the sense of coherence, i.e. comprehensibility, manageability and meaningfulness, build a stable way of seeing the world, challenges and life tasks that are considered worth the investment and involvement. Considered in this context, they also seem to be important in the implementation of the educational function of the nurse.

\section{AIM}

Assessment of the effectiveness of therapeutic education conducted by nurses working in the internal medicine wards in patients with diagnosed type 2 diabetes in the context of the sense of coherence. The article attempts to answer the question whether the components of the sense of coherence (comprehensibility, manageability and meaningfulness) are important for greater effectiveness of educational interactions.

\section{MATERIAL AND METHODS}

The study was conducted among one hundred nurses working in the wards of endocrinology, metabolic diseases, internal diseases and geriatrics, gastrology and hepatology, observation-internal medicine in the University Hospital in Cracow in the period from July to August 2017, after obtaining the consent of the hospital management. The study was conducted in accordance with the Declaration of Helsinki.

The study involved in 99\% women and in 1\% men, between the ages of 25 and 57 . The most representative group was made of people aged from 41 to 50 (46\%). The highest percentage of the surveyed had a bachelor's degree (51\%) and a master's degree (21\%), while the lowest percentage $(16 \%)$ completed medical studies. Most of the surveyed $(80 \%)$ were married and the others declared themselves as single. More than half of the surveyed (59\%) had 20 years of service. As many as $61 \%$ of the surveyed completed postgraduate studies and another $10 \%$ were currently in the process. The effectiveness of therapeutic education was assessed by means of the method of diagnostic survey, with the use of a survey questionnaire created by the authors. The authors' survey questionnaire consisted of two parts - the first, problem part and the second, socio-demographic part. The problem section was developed based on the subject literature. It contained 27 questions regarding conducted education in type 2 diabetes, including 16 closed, 9 half-open cafeteria-style and 2 open ones. To assess the level of the sense of coherence, a SOC-29 life orientation questionnaire was used in Polish language. The SOC-29 questionnaire allows to assess the sense of coherence of a respondent with three subscales: 
a sense of comprehensibility, manageability and meaningfulness. For the combined result, there are standards that allow to determine whether the respondent's sense of coherence is low, medium or high. The SOC-29 questionnaire (made available by a clinical psychologist) consists of 29 questions (in each question the respondent can choose a response from 1 to 7) grouped into three subscales [7]. The results of the research were subjected to statistical analyses using the following tests: chi-squared, Fisher's, t-Student's, Mann-Whitney, as well as ANOVA analysis of variance and Kruskal-Wallis analysis. The normality of the variable distribution was examined using the ShapiroWilk test. The analysis was carried out in the R program, version 3.4.1.

\section{RESULTS}

The analysis of the research results shows two trends in the therapeutic education carried out by nurses. The first one points to the professional preparation for carrying out the educational function. The second, however, to focusing only on the most important areas concerning the nature of the patient's disease and problems as well as to the preference for skill development, rather than transmitting theoretical knowledge.

The surveyed nurses declared that in preparation for the education they reached for the scientific literature $(83 \%)$; their important support was the knowledge gained during the qualification courses (20\%) and specialist courses such as diabetes educator (16\%). Almost all the nurses (98\%) admitted that they conducted education according to a chosen method, most often a mixed method, e.g. information-behavioural (72\%). The surveyed declared that they used different forms of education; the predominant one was an interview (84\%), instruction (76\%), demonstration (37\%) (percentages do not add up to a hundred, because the question was a multiple choice one). What speaks negatively for the surveyed, and it certainly has an impact on the quality of education, is the fact that over half of them (57\%) implemented educational tasks without using a previously prepared program. Moreover, the surveyed declared that the education very often has a one-off nature (49\%), which is openly contradictory to the rules of didactics. Although the nurses undertaking education, at an early stage assessed the patient's health status (91\%) and were aware of the current treatment $(64 \%)$, only about a third of them $(30 \%)$ paid attention to the psychosocial situation of the patient. The range of the undertaken subjects mainly included clinical aspects of disease (71\%), diet (77\%), insulin administration rules (84\%) or blood glucose measurement (95\%). Also in cooperation with other members of the therapeutic team, the same issues were dealt with, which on the one hand is an advantage (rule of regularity), but on the other hand - a drawback, as other subjects were treated cursorily, and by some surveyed people were not taken up at all. A particular deficit was visible in the area of social rights (mentioned by $8 \%$ of the surveyed) and coping with stress (15\%). The process of therapeutic education closes with giving final recommendations and $91 \%$ of the surveyed made such a summary. However, what should be noticed, they focused on dietary recommendations (85\%) and a check-up in the clinic (78\%). In comparison, 11\% of the surveyed mentioned coping with stress. Evaluation of conducted therapeutic education was carried out in the case of $41 \%$ of the surveyed with reference to theory and $81 \%$ with reference to practice. Oral responses (98\%) dominated for the assessment of theoretical knowledge while in order to control the acquired skills the following were used: $25 \%$ of demonstration and $56 \%$ of practice.

The analysis of the study results showed few statistically significant correlations between sociodemographic variables and the evaluation of therapeutic education. The number of educational methods used did not depend on the length of service ( $\mathrm{p}=0.611$ ), also the length of work was irrelevant for the use of educational programs $(p=0.967)$. However, the range of the covered subjects correlated with completed postgraduate education $(\mathrm{p}=0.001)$ (Tab. 1.). It was also shown that the surveyed undertaking further education used educational programs more often than other educators $(p=0.001)$ (Tab. 2.).

Tab. 1. Comparison of the completion of postgraduate education of respondents with the choice of the subject matter of undertaken health education

\begin{tabular}{|l|c|c|c|c|c|c|c|c|c|}
\hline \multirow{2}{*}{$\begin{array}{c}\text { Postgraduate } \\
\text { education }\end{array}$} & \multicolumn{7}{|c|}{ The number of discussed subjects } & \multirow{2}{*}{$\mathrm{p}^{*}$} \\
\cline { 2 - 12 } & $\mathrm{N}$ & Average & SD & Median & Min & Max & Q1 & Q3 & \\
\hline Yes & 62 & 4.95 & 1.43 & 5 & 1 & 7 & 4 & 6 & \\
\cline { 1 - 13 } & 38 & 3.82 & 1.54 & 4 & 1 & 7 & 3 & 4 & $<0.001$ \\
\hline
\end{tabular}

* Mann-Whitney test

Tab. 2. Comparison of the completion of postgraduate education of respondents with the education conducted on the basis of a previously prepared educational program

\begin{tabular}{|l|c|c|c|c|c|}
\hline \multirow{2}{*}{$\begin{array}{c}\text { Previously prepared } \\
\text { educational program }\end{array}$} & $\begin{array}{c}\text { Postgraduate education } \\
\text { (N=62) }\end{array}$ & \multicolumn{2}{|c|}{$\begin{array}{c}\text { Lack of postgraduate } \\
\text { education (N=38) }\end{array}$} & \multirow{2}{*}{$\mathrm{N}^{*}$} \\
\cline { 2 - 5 } & $\mathrm{n}$ & $\%$ & $\mathrm{n}$ & $\%$ & \\
\hline Yes & 38 & $61.29 \%$ & 5 & $13.16 \%$ & \multirow{2}{*}{$<0.001$} \\
\hline No & 24 & $38.71 \%$ & 33 & $86.84 \%$ & \\
\hline
\end{tabular}

* Chi-squared test

The statistical analysis of the results obtained by means of SOC-29 scale shows that the surveyed had an average (56\%) and a high (44\%) sense of coherence (Tab. 3.). The average score in comprehensibility scale was 48.91 $(\mathrm{SD}=8.39)$ and was slightly higher than the neutral level, which is 44 . It should be recognised then, that the surveyed had a high sense of comprehensibility (Tab. 4.). In manageability scale, the surveyed received 52.53 points $(\mathrm{SD}=8.87)$, which indicates a high level of the sense of manageability, therefore it was significantly higher than the neutral result, which is 40 . Similarly in the sense of meaningfulness scale 40.67 ( $\mathrm{SD}=5.9$ ), so it significantly exceeded the neutral result, which is 32 . Therefore, it should be acknowledged that the surveyed had a high sense of meaningfulness (Tab. 6.). 
Tab. 3. Point values for the sense of coherence of the surveyed individuals

\begin{tabular}{|l|l|c|c|}
\hline $\begin{array}{c}\text { SOC-29- number } \\
\text { of points }\end{array}$ & \multicolumn{1}{|c|}{ Interpretation } & $\begin{array}{c}\text { Number of the } \\
\text { surveyed (n) }\end{array}$ & $\begin{array}{c}\text { Percentage } \\
\text { value (\%) }\end{array}$ \\
\hline Up to 80 & Low sense of coherence & 0 & $0 \%$ \\
\hline $81-145$ & Medium sense of coherence & 56 & $56 \%$ \\
\hline $146-203$ & High sense of coherence & 44 & $44 \%$ \\
\hline Total & & 100 & $100 \%$ \\
\hline
\end{tabular}

Tab. 4. The sense of comprehensibility in the surveyed individuals

\begin{tabular}{|c|c|c|c|c|c|c|c|}
\hline N & Average & SD & Median & Min. & Max. & Q1 & Q3 \\
\hline 100 & 48.91 & 8.39 & 48.5 & 26 & 72 & 43 & 56 \\
\hline
\end{tabular}

Tab. 5. The sense of manageability in the surveyed individuals

\begin{tabular}{|c|c|c|c|c|c|c|c|}
\hline N & Average & SD & Median & Min. & Max. & Q1 & Q3 \\
\hline 100 & 52.53 & 8.87 & 53.5 & 31 & 69 & 47 & 59 \\
\hline
\end{tabular}

Tab. 6. The sense of meaningfulness in the surveyed individuals

\begin{tabular}{|c|c|c|c|c|c|c|c|}
\hline N & Average & SD & Median & Min. & Max. & Q1 & Q3 \\
\hline 100 & 40.67 & 5.9 & 40.5 & 22 & 51 & 37 & 46 \\
\hline
\end{tabular}

In the conducted studies, only two relations were confirmed between the sense of coherence and the effectiveness of education. Individuals with a high sense of coherence brought up a wider range of subjects in recommendation for patients than the surveyed with an average sense of coherence $(p=0.007)$ (Tab. 7.). Moreover, people with a high sense of coherence faced more difficulties in education than the remaining participants of the study $(\mathrm{p}=0.016)$ (Tab.8.). The obtained result may be connected with the fact that this group noticed various types of burdens which they indicated while providing answers in the survey questionnaire, time deficit in the profession of nurse, a small group of nursing staff with professional preparation for education and a general, too low number of nursing staff.

Tab. 7. The relationship between the number of subjects discussed in the course of education and the level of the sense of coherence of the surveyed individuals

\begin{tabular}{|l|c|c|c|c|c|c|c|c|c|}
\hline \multirow{2}{*}{$\begin{array}{c}\text { The sense } \\
\text { of } \\
\text { coherence }\end{array}$} & \multicolumn{7}{|c|}{ The number of subjects in recommendations } & \multirow{2}{*}{ * } \\
\cline { 1 - 11 } & Average & SD & Median & Min. & Max. & Q1 & Q3 & \\
\hline Medium & 56 & 2.16 & 1.17 & 2 & 0 & 4 & 2 & 3 & \\
\hline High & 44 & 2.77 & 0.91 & 3 & 0 & 5 & 2 & 3 & 0.007 \\
\hline
\end{tabular}

* Mann-Whitney test

Tab. 8. The relationship between the number of encountered factors hindering patients' education and the level of the sense of coherence of the surveyed individuals

\begin{tabular}{|l|c|c|c|c|c|c|c|c|c|}
\hline \multirow{2}{*}{$\begin{array}{c}\text { The sense } \\
\text { of } \\
\text { coherence }\end{array}$} & \multicolumn{7}{|c|}{ The number of encountered factors hindering patients' } & \multirow{2}{*}{ * } \\
\cline { 2 - 11 } & N & Average & SD & Median & Min. & Max. & Q1 & Q3 & \\
\hline Medium & 56 & 2.71 & 1.3 & 2.5 & 1 & 6 & 2 & 4 & \\
\hline High & 44 & 3.57 & 1.77 & 3 & 1 & 8 & 2 & 5 & \\
\hline
\end{tabular}

* Mann-Whitney test
The level of the sense of coherence did not depend on age, length of service, marital status, professional education and completed postgraduate studies of the surveyed nurse.

\section{DISCUSSION}

Our own studies, as well as the works of other authors, suggest that therapeutic education, conducted in an interdisciplinary team, is an important element of treatment and improvement of the quality of life of chronically ill patients.

The effectiveness of conducted therapeutic education can be assessed through the prism of systematic training, implementation of education on the basis of a prepared and evaluated program, using different methods and forms, maintenance of the required stages of the didactic process, periodicity of conducted classes as well as current and final evaluation of the effects.

The conducted research shows that the vast majority of the surveyed systematically attended specialist courses, trainings, specialization and other forms of postgraduate education. These results correspond to the studies of Lewtak and Poznańska, confirming the importance of knowledge, skills and positive attitudes of health care workers towards conducting health education in the context of completing specialization [8].

Nurses in their professional practice carried out health education using three methods: informational, behavioural and motivational. In our own studies, the vast majority of the nurses (72\%) in their professional practice combined informational and behavioural methods. The conducted education was most often (in over $75 \%$ of cases) based on conversation and instruction. Slightly less often (about 30-40\%) it was based on demonstrations, indicating literature and providing brochures and leaflets. While least often (less than 20\%) - on lectures, practice and case studies. Studies by Raczyńska et al. show that what the patient needs most is information support [9]. Similarly, in the studies by Pabis et al., nurses in their work used an interview as the main form of carrying out education [10].

The entire health education process should be planned in advance and carried out according to a developed and tested program [2]. Education conducted according to a logically structured multistage plan, called structured education, is one of the most effective ways of teaching [10, 11]. The respondents who completed postgraduate studies conducted education on the basis of a previously prepared program, which speaks for its greater effectiveness.

The sense of coherence is a key tool for modifying the course of confrontation with the conditions imposed by life, also professional life. People with a high sense of coherence are convinced that they will be able to manage both by means of their own resources as well as the others' to meet their internal and external needs, and they set a specific goal and life tasks, which they consider worth getting involved in[12]. Our own studies have shown that 56 out of 100 study participants (56\%) had an average and 44 respondents (44\%) had a high sense of coherence. 
The studies carried out by Kurowska et al. [13], Zaczyk [14], Basińska et al. [15], Kocięcka et al.[16] in professional groups of nurses have also confirmed an average level of self-efficacy. The results obtained by the authors showed few significant relationships between the sense of coherence and the effectiveness of education, therefore they point to the necessity of further, systematic searching.

\section{CONCLUSIONS}

1. The nurses who completed postgraduate studies more often educate patients on the basis of a previously prepared educational program and, moreover, they undertake a wider range of subjects than the people who did not complete such education.
2. The length of service does not matter to a properly conducted therapeutic education.

3. The surveyed with a high sense of coherence implement therapeutic education in a wider range than the people with an average sense of coherence.

4. The number of encountered factors hindering patients' education depends on the level of the sense of coherence. Individuals with a high sense of coherence face more difficulties than the surveyed with an average sense of coherence.

5. The sense of coherence level does not depend on age, length of service, marital status, professional education and completed postgraduate studies.

\section{OCENA EDUKACJI TERAPEUTYCZNEJ PROWADZONEJ PRZEZ PIELĘGNIARKI U PACJENTÓW Z CUKRZYCĄ TYPU 2 W KONTEKŚCIE POCZUCIA KOHERENCJI}

\section{WPROWADZENIE}

Wymogiem edukacji zdrowotnej jest podejmowanie działań międzysektorowych oraz interdyscyplinarnych, na rzecz pacjenta, objętego procesem edukacji. Złożoność problematyki edukacji dorosłych oraz różnorodność umiejętności osób, które są odpowiedzialne za jej prowadzenie, staje się wyzwaniem i wymaga zaangażowania różnych zasobów osobowych. W sektorze ochrony zdrowia ustawowy obowiązek edukacji zdrowotnej pacjenta przypisany jest zarówno zawodowi lekarza jak i pielęgniarki, czy innego członka zespołu terapeutycznego, który zajmuje się pacjentem i/lub jego krewnymi [1]. Realizacja edukacji terapeutycznej u pacjentów chorujących na cukrzycę typu 2 możliwa jest wówczas, gdy prowadzą ją osoby reprezentujące różne zawody i wszechstronną wiedzę z zakresu nie tylko nauk medycznych, ale też psychologii, pedagogiki i metodologii nauczania [2].

Edukacja zdrowotna pacjenta jest definiowana, jako „...proces obejmujący oddziaływanie wychowawcze i uczenie się, skierowane na pacjenta i/lub jego środowisko, czyli następujące kolejno, powiązane logicznie i przyczynowo czynności podejmowane w celu wywołania zmian w zachowaniu" [3].

Edukacja pacjenta zwłaszcza przewlekle chorego jest składową postępowania terapeutycznego i wskazane jest aby, towarzyszyła etapom diagnozowania, leczenia oraz pielęgnowania ułatwiając dzięki temu pacjentom podejmowanie w pełni świadomych decyzji dotyczących całego procesu terapeutyczno-opiekuńczego [1].

Edukacja diabetologiczna pacjenta przyczynia się do właściwego zrozumienia istoty choroby poprzez przekazanie wiedzy i poprawienie świadomości chorego. Dostarcza informacji choremu na temat samokontroli, zalecanego sposobu odżywiania i właściwej aktywności fizycznej, umiejętności rozpoznawania powikłań cukrzycy [4].

Należy uświadomić pacjentowi, że edukacja diabetologiczna i samokontrola są równorzędnymi i integralnymi elementami procesu leczenia oraz, że edukacja ta warunkuje poprawę jakości jego życia [5]. Istotnymi elementami edukacji diabetologicznej jest wspieranie i motywowanie chorych $[3,5]$.

Edukacja terapeutyczna jako proces ciągły, powinna być cyklicznie powtarzana aby utrwalić już zdobytą wiedzę teoretyczną i podawanie nowych wiadomości przy uwzględnieniu wykształcenia i poziomu inteligencji pacjenta $[1,2]$.

Proces edukacji wymaga zaangażowania, wysiłku i samodzielności, a ustawowa autonomia pielęgniarki w tym obszarze, powinna być wspierana za pomocą cech osobowości. Stworzona przez Antonowsky'ego koncepcja poczucia koherencji, definiowana, jako „... ogólna orientacja życiowa, postawa wobec życia i przekonanie, iż posiada ono sens i warto podejmować wyzwania, które ono przynosi" [6], wskazuje, że takie przekonanie wywiera istotny wpływ na postawy wobec wielu aktywności życiowych w tym wobec pracy zawodowej. Składowe poczucia koherencji, tj. zrozumiałość, zaradność i sensowność budują trwały sposób widzenia świata, wyzwań, zadań życiowych, które uznawane są za warte inwestycji i zaangażowania. Rozpatrywane w takim kontekście wydają się mieć także znaczenie w realizacji funkcji edukacyjnej pielęgniarki.

\section{CEL PRACY}

Ocena efektywności edukacji terapeutycznej realizowanej przez pielęgniarki u pacjentów z rozpoznaną cukrzycą typu 2 w kontekście poczucia koherencji. W pracy podjęto próbę odpowiedzi na pytanie, czy składające się na poczucie koherencji: zrozumienie, zaradność i sensowność mają znaczenie dla większej skuteczności prowadzonych oddziaływań edukacyjnych. 


\section{MATERIAt I METODY}

Badania przeprowadzono wśród stu pielęgniarek pracujących na oddziałach Endokrynologii, Chorób Metabolicznych, Chorób Wewnętrznych i Geriatrii, Gastrologii i Hepatologii, Obserwacyjno-Internistyczny w Szpitalu Uniwersyteckim w Krakowie od lipca do sierpnia 2017 r. po uzyskaniu zgody od Dyrekcji Szpitala na przeprowadzenie badań. Badania przeprowadzono zgodnie z Deklaracją Helsińską.

W badaniu uczestniczyło 99\% kobiet i 1\% mężczyzn, w przedziale wieku 25-57 lat. Najbardziej reprezentatywną grupę stanowili uczestnicy badania w przedziale wiekowym od 41 do 50 lat (46\%). Najwięcej osób posiadało wykształcenie wyższe licencjackie - 51\% i wyższe magisterskie $21 \%$, najniższy odsetek (16\%) ukończył studium medyczne. Większość badanych (80\%) pozostawała w związku małżeńskim, pozostali deklarowali się, jako osoby stanu wolnego. Ponad połowa badanych (59\%) posiadła 20 letni staż pracy. Aż 61\% badanych ukończyło kształcenie podyplomowe, a kolejne $10 \%$ było obecnie $\mathrm{w}$ trakcie jego realizacji. Do oceny efektywności edukacji terapeutycznej posłużono się metodę sondażu diagnostycznego, z wykorzystaniem kwestionariusza ankiety własnego autorstwa. Autorski kwestionariusz ankiety składa się z dwóch części - I część problemowa oraz II część społeczno-demograficzna. Część problemową opracowano na podstawie literatury przedmiotu. Zawarto w niej 27 pytań dotyczących prowadzonej edukacji w cukrzycy typu 2, w tym: 16 zamkniętych, $9 \mathrm{z}$ kafeterią półotwartą i 2 otwarte. Do oceny poziomu poczucia koherencji wykorzystano kwestionariusz orientacji życiowej SOC-29 w polskiej wersji językowej. Kwestionariusz SOC-29 pozwala ocenić poczucie koherencji u respondenta wraz z trzema podskalami: poczuciem zrozumienia, zaradności i sensu. Dla wyniku łącznego istnieją normy pozwalające stwierdzić, czy poczucie koherencji u danego respondenta jest niskie, średnie, czy wysokie. Kwestionariusz SOC-29 składa się z 29 pytań (w każdym pytaniu ankietowany może wybrać odpowiedź od 1 do 7) zgrupowanych w trzy podskale [7]. Wyniki badań poddano analizom statystycznym, posługując się testami: chi kwadrat, Fishera, t-Studenta, Manna-Whitney'a oraz analizą wariancji ANOVA oraz Kruskala-Wallisa. Normalność rozkładu zmiennych badano za pomocą testu Shapiro-Wilka. Analizę wykonano w programie $\mathrm{R}$, wersja 3.4.1.

\section{WYNIKI}

Analiza wyników badań wskazuje na dwie tendencje $\mathrm{w}$ realizowanej przez pielęgniarki edukacji terapeutycznej. Pierwsza, zwraca uwagę na profesjonalne przygotowanie do realizacji funkcji edukacyjnej. Druga, natomiast na koncentrowanie się na jedynie najważniejszych obszarach, dotyczących istoty choroby i problemów pacjenta, a także preferowaniu kształtowania umiejętności, bardziej, aniżeli przekazywaniu wiedzy teoretycznej.

Badane pielęgniarki deklarowały, że w przygotowaniu do edukacji sięgały do literatury naukowej (83\%), ważnym wsparciem dla nich, była wiedza nabyta w trakcie kursów kwalifikacyjnych (20\%) i specjalistycznych typu edukator w cukrzycy (16\%). Prawie wszystkie pielęgniarki przyznały (98\%), że prowadziły edukację według wybranej metody, najczęściej były to metody mieszane np. informacyjno-behawioralne (72\%). Osoby badane deklarowały korzystanie $\mathrm{z}$ różnych form edukacji, przeważała rozmowa indywidualna (84\%), instruktaż (76\%), pokaz (37\%) (procenty nie sumują się do stu, gdyż pytanie było wielokrotnego wyboru). Na niekorzyść badanych, mający niewątpliwie wpływ, na jakość edukacji przemawia fakt, iż ponad połowa (57\%) realizowało zadania edukacyjne, bez korzystania z wcześniej przygotowanego programu. Ponadto badani deklarowali, że edukacja bardzo często jest jednorazowa (49\%), co jawnie stoi w sprzeczności z zasadami dydaktyki. Co prawda, pielęgniarki podejmujące edukację na etapie wstępnym dokonywały oceny sytuacji zdrowotnej pacjenta (91\%) oraz orientowały się w aktualnym leczeniu (64\%), ale jedynie niespełna jedna trzecia z nich (30\%) zwracała uwagę na sytuację psychospołeczną chorego. Zakres podejmowanej tematyki w głównej mierze obejmował aspekty kliniczne choroby (71\%), stosowanie diety $(77 \%)$, zasady podawania insuliny $(84 \%)$, czy pomiar glikemii (95\%). Również we współpracy z innymi członkami zespołu terapeutycznego realizowane były te same tematy, co z jednej strony jest zaletą (zasada systematyczności), z drugiej zaś wadą, gdyż inne tematy traktowane były pobieżnie, a przez część osób badanych w ogólne niepodejmowane. Szczególny deficyt widoczny był w obszarze praw socjalnych, (o których wspomina $8 \%$ badanych) i radzeniu sobie ze stresem (15\%). Proces edukacji terapeutycznej zamykał udzielenie zaleceń końcowych, 91\% badanych dokonywała takiego podsumowania, jednakże, co należy zauważyć koncentrowały się one na zaleceniach dietetycznych (85\%) i kontroli w poradni (78\%). Dla porównania o radzeniu sobie ze stresem wspomniało $11 \%$ badanych. Ewaluacja prowadzonej edukacji terapeutycznej dokonywana była w przypadku $41 \%$ badanych w odniesieniu do teorii, a $81 \%$ w odniesieniu do praktyki. Dominowała postać odpowiedzi ustnej (98\%) dla oceny wiedzy teoretycznej, zaś pokaz (25\%) i ćwiczenia (56\%) dla kontroli nabytych umiejętności.

Analiza wyników badań wykazała nieliczne zależności istotne statystycznie między zmiennymi socjodemograficznymi a oceną edukacji terapeutycznej. Liczba stosowanych metod edukacji nie zależała od stażu pracy $(\mathrm{p}=0,611)$, również staż pracy nie miał znaczenia dla korzystania z programów edukacyjnych $(\mathrm{p}=0,967)$. Natomiast zakres podejmowanych tematów korelował $\mathrm{z}$ ukończonym kształceniem podyplomowym $(\mathrm{p}=0,001)$ (Tab. 1.).

Tab. 1. Porównanie ukończenia kształcenia podyplomowego respondentów z wyborem tematyki podejmowanej edukacji zdrowotnej

\begin{tabular}{|l|c|c|c|c|c|c|c|c|c|}
\hline \multirow{2}{*}{$\begin{array}{c}\text { Kształcenie } \\
\text { podyplomowe }\end{array}$} & \multicolumn{7}{|c|}{ Liczba omawianych tematów } & \multirow{2}{*}{ * } \\
\cline { 2 - 11 } & Średnia & SD & Mediana & Min & Max & Q1 & Q3 & \\
\hline Tak & 62 & 4,95 & 1,43 & 5 & 1 & 7 & 4 & 6 & \multirow{2}{*}{$<0,001$} \\
\hline Nie & 38 & 3,82 & 1,54 & 4 & 1 & 7 & 3 & 4 & \\
\hline
\end{tabular}

* Test Manna-Whitney'a 
Wykazano także, że badani podejmujący dalsze kształcenie korzystali z programów edukacyjnych częściej, niż pozostali edukatorzy $(\mathrm{p}=0,001)$ (Tab. 2.).

Tab. 2. Porównanie ukończenia kształcenia podyplomowego respondentów z edukacją prowadzoną w oparciu o wcześniej przygotowany program edukacyjny

\begin{tabular}{|l|c|c|c|c|c|}
\hline \multirow{2}{*}{$\begin{array}{c}\text { Wcześniej } \\
\text { przygotowany } \\
\text { program edukacyjny }\end{array}$} & \multicolumn{2}{|c|}{$\begin{array}{c}\text { Kształcenie } \\
\text { podyplomowe (N=62) }\end{array}$} & \multicolumn{2}{c|}{$\begin{array}{c}\text { Brak kształcenia } \\
\text { podyplomowego (N=38) }\end{array}$} & \multirow{2}{*}{ * * } \\
\cline { 2 - 5 } & $\mathrm{n}$ & $\%$ & $\mathrm{n}$ & $\%$ & \\
\hline Tak & 38 & $61,29 \%$ & 5 & $13,16 \%$ & \multirow{2}{*}{$<0,001$} \\
\hline Nie & 24 & $38,71 \%$ & 33 & $86,84 \%$ & \\
\hline
\end{tabular}

${ }^{*}$ Test chi-kwadrat

Analiza statystyczna wyników uzyskanych za pomocą Skali SOC-29, wskazuje, że badane osoby cechowały się średnim (56\%) i wysokim (44\%) poczuciem koherencji (Tab. 3.). Średnia liczba punktów w skali zrozumienia wynosiła $48,91(\mathrm{SD}=8,39)$ i była nieco wyższa od poziomu neutralnego, który wynosi 44 . Zatem należy uznać, że osoby badane cechowały się wysokim poczuciem zrozumienia (Tab. 4.). W skali zaradności osoby badane uzyskały 52,53 punkty $(\mathrm{SD}=8,87$ ), co wskazuje na wysoki poziom poczucia zaradności, była ona zauważalnie wyższa od wyniku neutralnego, który wynosi 40. Zatem należy uznać, że osoby badane cechowały się wysokim poziomem poczucia zaradności (Tab. 5.). Podobnie w skali poczucia sensu 40,67 (SD = 5,9) zauważalnie przekraczała wynik neutralny, który wynosi 32. Zatem należy uznać, że osoby badane cechowały się wysokim poczuciem sensu. (Tab. 6.).

Tab. 3. Wartości punktowe dla poczucia koherencji osób badanych

\begin{tabular}{|l|l|c|c|}
\hline $\begin{array}{c}\text { SOC-29- liczba } \\
\text { punktów }\end{array}$ & \multicolumn{1}{|c|}{ Interpretacja } & $\begin{array}{c}\text { Liczba } \\
\text { badanych } \\
(\mathrm{n})\end{array}$ & $\begin{array}{c}\text { Wartość } \\
\text { procentowa } \\
(\%)\end{array}$ \\
\hline D0 80 & Niskie poczucie koherencji & 0 & $0 \%$ \\
\hline $81-145$ & Średnie poczucie koherencji & 56 & $56 \%$ \\
\hline $146-203$ & Wysokie poczucie koherencji & 44 & $44 \%$ \\
\hline Razem & 100 & $100 \%$ \\
\hline
\end{tabular}

Tab. 4. Poczucie zrozumienia u osób badanych

\begin{tabular}{|c|c|c|c|c|c|c|c|}
\hline N & Średnia & SD & Mediana & Min & Max & Q1 & Q3 \\
\hline 100 & 48,91 & 8,39 & 48,5 & 26 & 72 & 43 & 56 \\
\hline
\end{tabular}

Tab. 5. Poczucie zaradności u osób badanych

\begin{tabular}{|c|c|c|c|c|c|c|c|}
\hline N & Średnia & SD & Mediana & Min & Max & Q1 & Q3 \\
\hline 100 & 52,53 & 8,87 & 53,5 & 31 & 69 & 47 & 59 \\
\hline
\end{tabular}

Tab. 6. Poczucie sensu u osób badanych

\begin{tabular}{|c|c|c|c|c|c|c|c|}
\hline N & Średnia & SD & Mediana & Min & Max & Q1 & Q3 \\
\hline 100 & 40,67 & 5,9 & 40,5 & 22 & 51 & 37 & 46 \\
\hline
\end{tabular}

W przeprowadzonych badaniach potwierdzono jedynie dwie zależności między poczuciem koherencji, a efektywnością edukacji. Osoby z wysokim poczuciem koherencji poruszały w zaleceniach dla pacjenta szerszy zakres tematyczny, aniżeli badani ze średnim poczuciem koherencji ( $\mathrm{p}=0,007)$ (Tab. 7.). Ponadto osoby cechujące się wysokim poczuciem koherencji, napotykały na więcej trudności w edukacji, aniżeli pozostali uczestnicy badań ( $\mathrm{p}=0,016)$ (Tab. 8.). Uzyskany wynik może być związany z faktem dostrzegania przez tą grupę badanach różnego typu obciążeń, na które wskazywali udzielając odpowiedzi w kwestionariuszu ankiety, tj. deficytu czasu w pracy zawodowej pielęgniarek, małej grupie personelu pielęgniarskiego z profesjonalnym przygotowaniem do edukacji oraz ogólnej zbyt niskiej liczbie personelu pielęgniarskiego.

Tab. 7. Zależność pomiędzy liczbą tematów poruszanych w toku edukacji a poziomem poczucia koherencji osób badanych

\begin{tabular}{|l|c|c|c|c|c|c|c|c|c|}
\hline \multirow{2}{*}{$\begin{array}{c}\text { Poczucie } \\
\text { koherencji }\end{array}$} & \multicolumn{7}{|c|}{ Lizzba tematów poruszanych w zaleceniach } & \multirow{2}{*}{ * } \\
\cline { 2 - 11 } & N & Średnia & SD & Mediana & Min & Max & Q1 & Q3 & \\
\hline Średnie & 56 & 2,16 & 1,17 & 2 & 0 & 4 & 2 & 3 & \\
\hline Wysokie & 44 & 2,77 & 0,91 & 3 & 0 & 5 & 2 & 3 & \\
\hline
\end{tabular}

* Test Manna-Whitney'a

Tab. 8. Zależność pomiędzy liczbą napotykanych czynników utrudniających edukację pacjentów a poziomem poczucia koherencji osób badanych

\begin{tabular}{|l|c|c|c|c|c|c|c|c|c|}
\hline \multirow{2}{*}{$\begin{array}{c}\text { Poczucie } \\
\text { koherencii }\end{array}$} & \multicolumn{8}{|c|}{ Liczba napotykanych czynników utrudniających edukację } & \multirow{2}{*}{ pacjentów } \\
\cline { 2 - 10 } & N & Średnia & SD & Mediana & Min & Max & Q1 & 03 & \\
\hline Średnie & 56 & 2,71 & 1,3 & 2,5 & 1 & 6 & 2 & 4 & \multirow{2}{*}{0,016} \\
\hline Wysokie & 44 & 3,57 & 1,77 & 3 & 1 & 8 & 2 & 5 & \\
\hline
\end{tabular}

* Test Manna-Whitney'a

Poziom poczucia koherencji nie zależał od wieku, stażu pracy, stanu cywilnego, wykształcenia zawodowego i ukończonego kształcenia podyplomowego badanych pielęgniarek.

\section{OMÓWIENIE}

Z przeprowadzonych badań własnych, jak również prac innych autorów wynika, że edukacja terapeutyczna, prowadzona w zespole interdyscyplinarnym jest ważnym elementem leczenia i poprawy jakości życia osób chorych przewlekle.

Efektywność prowadzonej edukacji terapeutycznej można oceniać przez pryzmat systematycznego dokształcania, realizowania edukacji w oparciu o przygotowany i ewaluowany program, stosowania zróżnicowanych metod i form, zachowania wymaganych etapów procesu dydaktycznego, cykliczności prowadzonych zajęć oraz bieżącej i końcowej ewaluacji efektów.

Z przeprowadzonych badań wynika, że zdecydowana większość badanych systematycznie uczęszczała na kursy specjalistyczne, szkolenia, specjalizacje i inne formy kształcenia podyplomowego. Wyniki te korespondują z badaniami Lewtak i Poznańskiej potwierdzającymi znaczenie posiadanej wiedzy, umiejętności oraz pozytywnych postaw pracowników ochrony zdrowia wobec prowadzenia edukacji zdrowotnej w kontekście ukończenia specjalizacji [8]. 
Pielęgniarki w swojej praktyce zawodowej prowadziły edukację zdrowotną według trzech metod: informacyjnej, behawioralnej i motywacyjnej. W badaniach własnych zdecydowana większość pielęgniarek (72\%) w swojej praktyce zawodowej łączyła metody informacyjne $z$ behawioralnymi. Prowadzona edukacja najczęściej (ponad 75\% przypadków) opierała się na rozmowie i instruktażu. Nieco rzadziej (ok. 30-40\%) na pokazach, wskazaniu literatury i przekazaniu broszur oraz ulotek. Najrzadziej zaś (poniżej 20\%) na wykładach, ćwiczeniach i opisach przypadków. Badania autorstwa Raczyńskiej i wsp. wykazały, że pacjent najbardziej potrzebuje wsparcia informacyjnego [9]. Podobnie w badaniach Pabiś i wsp. pielęgniarki w swojej pracy stosowały rozmowę jako główną formę prowadzenia edukacji [10].

Cały proces edukacji zdrowotnej powinien być wcześniej zaplanowany oraz prowadzony według opracowanego i sprawdzonego programu [2]. Edukacja prowadzona według logicznie uporządkowanego wieloetapowego planu nazywana ustrukturyzowaną należy do najbardziej efektywnych sposobów edukacji [10,11]. Respondenci, którzy ukończyli kształcenie podyplomowego prowadzili edukację w oparciu o wcześniej przygotowany program, co przemawia, za większą jej skutecznością.

Poczucie koherencji jest kluczowym narzędziem do modyfikowania przebiegu konfrontacji z warunkami stawianymi przez życie, również to zawodowe. Osoby z wysokim poczuciem koherencji mają przeświadczenie, że będą umieć sobie poradzić, zarówno przy pomocy zasobów własnych jak i innych, aby zaspokoić potrzeby wewnętrzne i zewnętrzne, stawiają określone cele i zadania życiowe, które uznają za warte zaangażowania [12]. Badania własne pokazały, że 56 spośród 100 uczestników badania (56\%) miało średnie, a 44 ankietowanych (44\%) wysokie poczucie koherencji. Badania przeprowadzone przez Kurowską i wsp. [13], Zaczyk [14], Basińską i wsp. [15], Kocięcką i wsp. [16] w grupach zawodowych pielęgniarek także potwierdziły średni poziom poczucia własnej skuteczności. Uzyskane wyniki własne, ukazujące nieliczne istotne zależności między poczuciem koherencji, a efektywnością edukacji wskazują na konieczność dalszych, systematycznych poszukiwań.

\section{WNIOSKI}

1. Pielęgniarki, które ukończyły kształcenie podyplomowe częściej edukują pacjentów w oparciu o wcześniej przygotowany program edukacyjny, ponadto podejmują szerszy wachlarz tematów niż osoby, które takiego kształcenia nie odbyły.

2. Staż pracy nie ma znaczenia dla prawidłowo prowadzenie edukacji terapeutycznej.
3. Badani z wysokim poczuciem koherencji realizują edukację terapeutyczną w szerszym zakresie, niż osoby ze średnim poczuciem koherencji.

4. Liczba napotykanych czynników utrudniających edukację pacjentów zależy od poziomu poczucia koherencji. Osoby z wysokim poczuciem koherencji napotykają więcej trudności, aniżeli badani cechujący się średnim poczuciem koherencji.

5. Poziom poczucia koherencji nie zależy od wieku, stażu pracy, stanu cywilnego, wykształcenia zawodowego i ukończonego kształcenia podyplomowego.

\section{REFERENCES}

1. Woynarowska B. Edukacja zdrowotna. Warszawa: Wyd. PWN; 2010

2. Dębska G, Rogala-Pawelczyk G, Zięba E. Projekt edukacji chorego z zespołem stopy cukrzycowej opartej na teorii Dorothy Orem. Piel. Zdr. Pub. 2012; 2 (1):57-65.

3. Van Damme-Ostapowicz K, Krajewska-Kułak E. Standard edukacji pielęgniarskiej wobec pacjentów z zakresu medycyny podróży. Probl. Pielęg. 2013; 12 (1):1-6.

4. Chudiak A, Lomper K, Jankowska-Polańska B, Uchmanowicz I. Wpływ edukacji diabetologicznej na ocenę jakości życia chorych z cukrzycą typ 2. Probl. Pielęg. 2015; 23:1-5.

5. Kostrzewa-Zabłocka E, Kulesza B. Samokontrola, jako nieodłączna część leczenia cukrzycy, poprawy jakości życia izdrowia oraz sposób na zapobieganie powikłaniom. Zdr. i dobrostan. 2014; 2:79-89.

6. Heszen I, Sęk H. Psychologia zdrowia. Warszawa: Wyd. PWN; 2008.

7. http://www.psychologia.net.pl/testy.php?test=soc [Data dostępu 03.04.2017]

8. Lewtak K, Poznańska A. Uwarunkowania prowadzenia edukacji zdrowotnej pacjentów przez lekarzy podstawowej opieki zdrowotnej. Prz. Epidemiol. 2012; 66:697-704.

9. Raczyńska G, Jędrzejkiewicz B, Sykut A, Dobrowolska B. Udział pielęgniarki w działaniach edukacyjnych podnoszących poziom świadomości pacjentów na temat profilaktyki raka jelita grubego. J. Educ. Health and Sport. 2016; 6(11):195-204

10. Pabiś M, Ślusarska B, Jarosz M, Zarzycka D. i wsp. Kompetencje pielęgniarek w zakresie edukacji zdrowotnej w polskim systemie opieki medycznej. Piel. XXI wieku, 2010; 3-4: 32-33.

11. Polskie Towarzystwo Diabetologiczne. Zalecenia kliniczne dotyczące postępowania u chorych na cukrzycę 2016. Diabetol. Kliniczna. 2016; Supl. A:1-84.

12. Łapińska M, Gaworska-Krzemińska A, Dominiak K, i wsp. Poczucie koherencji a odporność na stres wśród położnych jako predyktory samodzielności zawodowej. Probl. Pielęg. 2013; 21(3):306-317.

13. Kurowska K, Maciaszek A, Haor B, Rezmerska L. Poczucie koherencji a wypalenie u czynnych zawodowo pielęgniarek. Piel. Chir. Angiolog. 2011; 1:23-30.

14. Zaczyk I. Occupational burnout and the sense of coherence among pediatric nurses. Zdr. Publ. 2010; 120 (4):417-420

15. Basińska M, Andruszkiewicz A, Grabowska M. Nurses' sense of coherence and their work related patterns of behavior. J. Occup. Environ. Med. 2011; 24 (3):256-266.

16. Kocięcka A, Andruszkiewicz A, Wrońska I. Poczucie koherencji a stan zdrowia pielęgniarek czynnych zawodowo. Probl. Pielęg. 2010; 18 (2):139-144.

Manuscript received: 03.11 .2017

Manuscript accepted: 28.12.2017

Tłumaczenie/Translation: Anna Moskała 